\title{
Systemy i transfery. Z Krisem Van Heuckelomem rozmawia Magdalena Machała
}

\author{
Systems and Transfers. Kris Van Heuckelom in Conversation \\ with Magdalena Machała
}

Magdalena Machała (M.M.): Chciałabym zacząć od pytania o najnowszą książkę Justina Quinna Between Two Fires: Transnationalism and Cold War Poetry, o której pisze Aleksandra Kremer w artykule wstępnym tego numeru. Badając relacje między literaturą czeską a literaturą anglojęzyczną (szczególnie amerykańska), autor podkreśla, że interesuje go nie tyle kwestia przekładów - ich obecność czy nieobecność na rynku wydawniczym - ile rozmaitych przemieszczeń, przesunięć interpretacyjnych, które zachodzą podczas wymiany między kulturami i literaturami. Jedną z tez tej książki eksponuje Kremer, pisząc, że według Quinna „różne obiegi zagraniczne poszczególnych prac nie są wynikiem samych tylko przypadków, mechanizmów rynkowych, indywidualnych zabiegów i problemów z przekładem. Quinn dostrzega w nich wpływy znacznie większych zjawisk i procesów. (...) kultury biorą sobie po prostu to, czego w danym momencie potrzebują”. Czy to ujęcie - jak i cała książka - wydają się Panu nowatorskie, inspirujące i otwierające? Czy według Pana pozwala spojrzeć na sieć relacji między poszczególnymi literaturami w inny sposób?

Kris Van Heuckelom (K.V.H.): Jeśli chodzi o książkę Quinna, mam mieszane uczucia, bo z jednej strony to, o czym pisze autor, jest bardzo ciekawe i słuszne, a z drugiej strony chyba nie jest też takie nowe. To jest bardzo ciekawa, dobrze napisana i bardzo wartościowa książka, ale na przykład twierdzenie, które Pani zacytowała, że każda kultura bierze dla siebie to, czego potrzebuje, nie jest żadną nową czy rewolucyjną tezą, może jest nawet trochę trywialne. W komparatystyce i translatologii przez ostatnich kilka dekad bardzo dużo pisano o przepływach z jednej kultury do drugiej, o tym, że to zwykle kultura docelowa ma większy wpływ na to, co dzieje się z tłumaczonym tekstem. Wydaje mi się, że Quinn nawiązuje właśnie do izraelskiego badacza Itamara Evena-Zohara - założyciela szkoły, która zajmuje się literaturą z punktu widzenia polisystemowości. Według Evena-Zohara literatura jest jak duży system, który składa się z różnych podsystemów. Badacz poświęcił też wiele uwagi roli, jaką w obrębie konkretnego systemu odgrywają przekłady, więc jeżeli chodzi 
o przepływy z jednego systemu narodowego do drugiego, to już zostało w dużej mierze opisane i zbadane. Przedstawiciele tej samej szkoły zwracają uwagę także na to, że jeśli kultura docelowa wprowadza jakiś przekład, często dochodzi do pewnego rodzaju manipulacji - ten transfer służy jakiemuś celowi. Oczywiście to wszystko brzmi bardzo negatywnie, ale jeśli jakiś tekst jest tłumaczony, wynika to z żywego zainteresowania danym autorem, książką, powieścią, więc nie o to chodzi. Ja również jestem tłumaczem i kiedy przekładam wiersze polskiego poety, najczęściej jestem zainteresowany tym autorem czy tekstem. W teorii Evena-Zohara chodzi raczej o różne normy kulturowe, do których przystosowują się poszczególni ludzie, więc ja, jako tłumacz należący do podsystemu niderlandzkojęzycznego, podlegam pewnym prawom oraz regułom i kiedy chcę wprowadzić do tego podsystemu jakiegoś polskiego pisarza, muszę się do tych reguł przystosować. Według teorii polisystemów przekłady zajmują marginalne miejsce w danym systemie, ale niekiedy jednak tłumaczone teksty mogą się przenieść z peryferii systemu do centrum, jeżeli w danym systemie występują jakiś kryzys, konflikt czy luka.

M.M.: W jednej z ankiet dotyczących recepcji literatury polskiej w Belgii Katia Vandenborre, literaturoznawczyni i polonistka z Wolnego Uniwersytetu w Brukseli, wspomina o kryzysie, jaki przechodzi teraz współczesna literatura belgijska, także o zmianie statusu literatury w belgijskim społeczeństwie. W kontekście kryzysu w obrębie własnej literatury Vandenborre wspomina o „rozkwicie” współczesnej literatury polskiej, podkreślając, że w Belgii kojarzy się ona przede wszystkim z poezją.

K.V.H.: Tak, to jest dobry przykład. Mimo że teraz ta faza w dużej mierze minęła, dobrze pamiętam ten czas. To było około roku 2000, to znaczy po Nagrodzie Nobla dla Wisławy Szymborskiej oraz po powrocie Czesława Miłosza do Polski, kiedy powstał mit Krakowa jako miasta poezji, miasta noblistów. Mam kolegę tłumacza, który jest Belgiem, ale jego matka jest Polką. W czasie wojny przebywała w obozie niemieckim, gdzie poznała Belga. Po wojnie wzięli ślub i zamieszkali w Belgii. Jej syn bardzo słabo mówi po polsku, ale ma ogromny sentyment do Polski jako kraju poezji i niemal w każdym artykule, w każdej recenzji wspominał o tym, że kiedy wchodzi się do polskiej księgarni, widzi się półki uginające się pod ciężarem tomików poetyckich. To oczywiście przerysowany obraz, ale tak w pewnym momencie u nas funkcjonował. Po śmierci Szymborskiej, która była u nas bardzo popularna, zainteresowanie współczesną poezją polską trochę przygasło (choć nie do końca minęło), a teraz można chyba obserwować zwrot do prozy polskiej związany również z Nagrodą Nobla dla Olgi Tokarczuk. Warto tu także wspomnieć o twórczości Wiesława Myśliwskiego, która doczekała się kilku tłumaczeń na język niderlandzki w ostatniej dekadzie. 
M.M.: Myślę, że zwrot, o którym Pan mówi, ma też związek z przemianami w obrębie literatury polskiej, w której poezja odgrywa chyba coraz mniejszą rolę. Wydaje mi się, że przeciętny polski czytelnik miałby problem z wymienieniem choć kilku nazwisk współczesnych polskich poetów i poetek. Także w księgarniach, jeśli półka ze współczesną polską poezją w ogóle istnieje, zazwyczaj zajmuje marginalne miejsce.

K.V.H.: Tak, tak, a wracając jeszcze do przekładów, jest taki znany przykład historyczny z drugiej połowy XIX wieku. W literaturze francuskiej rozwijał się w tym czasie naturalizm, ale niektórzy pisarze uważali, że za dużo w tym nurcie pesymizmu i nędzy i wtedy właśnie, w latach osiemdziesiątych, francuski dyplomata, który przez wiele lat mieszkał w Rosji i znał rosyjski, Eugène-Melchior de Vogüé, napisał książkę na temat powieści rosyjskiej. Europa Zachodnia odkryła wówczas literaturę rosyjska, która do tej pory była mało znana. Wprawdzie czytano Aleksandra Puszkina, ale ten prawdziwy przewrót nastąpił dopiero pod koniec XIX wieku. Znów oznacza to, że był jakiś kryzys w systemie literatury francuskiej, dlatego ktoś sprowadził z zagranicy nowy ruch. Ponownie możemy także zauważyć pewnego rodzaju manipulację, ponieważ ten zagraniczny autor w pewnym sensie służy nam do pokonania kryzysu w systemie docelowym.

M.M.: Przychodzi mi teraz na myśl przykład związany z recepcją poezji Szymborskiej we Włoszech. Włoska literaturoznawczyni i polonistka Giovanna Tomassucci, zastanawiając się nad fenomenem popularności poetki w swoim kraju, także pisała o pewnym kryzysie w poezji włoskiej. Badaczka stwierdza, że popularność Szymborskiej była „zdrową reakcją” czytelników na „niedostatki włoskiej poezji" - hermetycznej i niejasnej ${ }^{1}$.

K.V.H.: Tak, te przykłady na pewno można by mnożyć i dlatego myślę, że ta teza Quinna nie jest aż tak odkrywcza, bo zazwyczaj jest tak, że nowy tłumaczony tekst pełni jakąś funkcję w innym systemie, że istnieje luka, którą trzeba wypełnić, i kultura docelowa projektuje pewne wewnętrzne potrzeby na tę literaturę zagraniczną, która zostaje importowana. Ta teza wydaje mi się więc dość trywialna, podobnie jak rozważania Quinna dotyczące żelaznej kurtyny, a zwłaszcza stwierdzenie, że nie była ona taka szczelna. Jest taki stereotyp, że istniała żelazna kurtyna i nie było żadnych przepływów, ale wszyscy wiedzą, że były różne transfery i podróże, tylko ludzie po prostu lubią myśleć w kategoriach binarnych opozycji, czyli że był Wschód i Zachód oraz żelazna granica, która uniemożliwiała jakiekolwiek kontakty. Każdy, kto zajmuje się historią komunizmu w Europie Środkowo-Wschodniej, wie, że te obustronne

1 G. Tomassucci, Niektórzy lubią Szymborską, „Nowa Dekada Krakowska” 2016, nr 6, s. $44-45$. 
kontakty istniały, więc ta teza także nie jest zbyt odkrywcza, ale bardzo ciekawe w tej książce jest to, że Quinn skupia się na mniejszych obszarach. Wśród powszechnych wyobrażeń dotyczących zimnej wojny wciąż funkcjonuje wyraźny podział na Zachód, czyli Stany Zjednoczone, oraz Wschód, czyli Związek Radziecki, a to były te główne mocarstwa. Badacze przez wiele lat skupiali się przede wszystkim na konflikcie kulturowym między tymi państwami. Mniej więcej od piętnastu lat istnieje nowy kierunek badań - cold war cultural studies - $\mathrm{i}$ właśnie w ramach tej dziedziny bardzo dużo mówi się zarówno o tym, że żelazna kurtyna wcale nie była taka szczelna, jak i o tym, że te kontakty istniały również na niższych poziomach, czyli nie tylko między dwoma wielkimi mocarstwami, ale także między ludźmi i instytucjami na niższych szczeblach oraz między krajami „mniej ważnymi”, co Quinn określa jako minor transnationalism. W jego książce mowa na przykład o kontaktach między Irlandią a Czechosłowacją. Literatura irlandzka pisana jest oczywiście w języku angielskim, więc w pewnym sensie jest to „literatura większa”, ale skoro Irlandia ma przeszłość kolonialną i uchodzi za kraj postkolonialny w stosunku do Wielkiej Brytanii, można powiedzieć, że także była na marginesie tego konfliktu. Czechosłowacja wchodziła w skład bloku wschodniego, ale też zajmowała miejsce raczej marginalne. Quinn skupia się więc na transferach między mniejszymi krajami, mniejszymi literaturami i okazuje się, że kontaktów między nimi było bardzo dużo i miały one charakter wielostronny. Bardzo ciekawy jest rozdział o Seamusie Heaneyu i Miroslavie Holubie, czyli mało znanym poecie, który w Wielkiej Brytanii uchodził za bardzo ważnego pisarza. Wydaje mi się, że takich historii jest więcej. Ta książka jest tak znacząca, ponieważ idzie innym tropem, autor nie skupia się na głównym konflikcie, ale na mniejszych krajach, mniejszych kulturach, które również były angażowane w te różne zimnowojenne transfery.

\section{Literatura polska i belgijska: transfer wielokierunkowy}

M.M.: Ciekawe w tej książce jest też to, że Quinn opiera się w dużej mierze na własnym doświadczeniu, opisuje swoje podróże do Czechosłowacji i rozmowy o literaturze zarówno z przypadkowymi mieszkańcami Pragi, jak i z ludźmi żywo zainteresowanymi literaturą. Zastanawiam się, jakie polskie teksty są najchętniej tłumaczone w Niderlandach i czym różni się ich obieg akademicki od tego, co przeciętny czytelnik może znaleźć w księgarniach.

K.V.H.: Wrócę jeszcze tylko na moment do poprzedniego wątku, czyli do transferów między mniejszymi literaturami. Jestem polonistą i bardzo interesuję się literaturą polską, ale jestem Belgiem mówiącym po niderlandzku, więc moja działka to też częściowo literatura niderlandzka i dlatego ta książka Quinna jest dla mnie taka ciekawa, ponieważ moja literatura jest również literaturą 
mniejszą. Nasza literatura jest jeszcze mniejsza niż literatura polska, bo Niderlandy - czyli Holandię i północną część Belgii - zamieszkuje około 25 milionów mieszkańców, a Polska to większy kraj, ale myślę, że status tych dwu literatur jest podobny. Mam sporo kolegów niderlandystów, którzy zajmują się recepcją literatury niderlandzkiej w Polsce, a ja z kolei zajmuję się recepcją literatury polskiej w Belgii i Holandii, więc może, nawiązując do tych badań, opowiem o bardzo ciekawej sytuacji z XIX wieku. W tym czasie literatura francuska czy niemiecka, czyli centrum, pełniły funkcję pomostu. Nie było wtedy tłumaczy, którzy potrafiliby tłumaczyć z języka polskiego na niderlandzki, więc zazwyczaj korzystano z przekładów niemieckich i francuskich. To działało w obie strony - zarówno polskie tłumaczenia literatury niderlandzkiej, jak i niderlandzkie tłumaczenia literatury polskiej powstawały na podstawie francuskich czy niemieckich tekstów. Tych dziewiętnastowiecznych przekładów jest bardzo niewiele, ale są one bardzo ciekawe, ponieważ dobrze pokazują, jak każda kultura bierze dla siebie to, czego w danym momencie potrzebuje. Większość dziewiętnastowiecznych tłumaczeń polskich tekstów na język niderlandzki dotyczy tematyki żydowskiej. To nie jest najważniejszy temat w literaturze polskiej XIX wieku, a okazuje się, że dla czytelników niderlandzkojęzycznych był on bardzo ważny. Jest na przykład taka bardzo mało znana powieść Juliana Ursyna Niemcewicza Lejbe i Siora. Nie wiem, czy Pani kojarzy...

M.M.: Nie słyszałam i nie czytałam...

K.V.H.: A to jest jeden z najstarszych przekładów literatury polskiej na język niderlandzki. Okazuje się więc, że powieść bardzo mało znana w Polsce u nas wywołała ogromną dyskusję. To dość kontrowersyjna książka, która mówi o potrzebie emancypacji polskich Żydów, o tym, że powinni zrezygnować ze wszystkich starych tradycji, posługiwać się językiem polskim itd.

W Polsce reakcje na tę książkę były ograniczone i raczej negatywne, a u nas spotkała się ona z dużym zainteresowaniem, pojawiło się sporo recenzji i nawet powstała książeczka w języku niderlandzkim w całości poświęcona powieści Niemcewicza. Jaką rolę odegrał ten utwór? Tematyka emancypacji Żydów była bardzo aktualna zarówno w ówczesnej Polsce, to znaczy w Polsce w czasie rozbiorów, jak i w Niemczech, a także w Niderlandach. U nas również istniało bardzo duże skupisko Żydów, którzy byli już w trakcie asymilacji, a książka Niemcewicza mogła pełnić ważną funkcję w tym procesie. Ta powieść jest dość radykalna, dlatego holenderscy wydawcy byli nią zainteresowani. Okazało się bowiem, że oto jakiś polski autor pisze, czym tak naprawdę jest asymilacja. Ten przykład bardzo dobrze pokazuje, że w transferach międzykulturowych bardzo często chodzi o potrzeby kultury docelowej. Nie mamy w tym czasie żadnych przekładów dzieł Adama Mickiewicza ani innych wielkich polskich pisarzy tego okresu, ale jest kilka powieści o tematyce żydowskiej. Kolejnym przekładem jest powieść Meir Ezofowicz Elizy Orzeszkowej, czyli to już ostatnia ćwierć 
XIX wieku. Tematyka żydowska stanowi więc nić przewodnią i wzbudza zainteresowanie wśród niderlandzkich czytelników i tłumaczy. Jednocześnie były też transfery w drugą stronę, ale miały one zupełnie inny charakter. Nie pamiętam, czy Quinn o tym pisze, ale te relacje mają zazwyczaj charakter asymetryczny, ponieważ zarówno kultura docelowa ma pewne potrzeby, jak i kultura źródłowa, z której się czerpie, ma swoje potrzeby, więc bierze dla siebie coś innego.

Na przykład w XIX wieku w Polsce istniało bardzo wiele tłumaczeń tekstów belgijskiego pisarza, który specjalizował się w powieściach historycznych i obyczajowych pisanych w duchu nacjonalistycznym i właśnie ten autor był bardzo popularny w Europie Środkowej. W Polsce nazywano go nawet flamandzkim Kraszewskim. My sięgnęliśmy więc po tematykę żydowską, a wy po narodowościową. Oczywiście w XIX wieku te książki były przekładane w bardzo nierzetelny sposób, więc dość łatwo można było manipulować tekstami i wykorzystywać je w pewnych celach kulturowych. W XX wieku to się zmieniło, ponieważ mamy do czynienia z przekładami bezpośrednimi, w których jest mniej ingerencji tłumaczy.

M.M.: Samoświadomość tłumaczy jest też dużo większa.

K.V.H.: Tak, to z pewnością. Kilka lat temu odbyła się w Brukseli konferencja na temat różnych przepływów między literaturą niderlandzką a literaturami z Europy Środkowo-Wschodniej i ona także uświadomiła nam, jak wiele jest relacji między mniejszymi krajami i literaturami. U nas na przykład w pewnym momencie bardzo popularny był Zbigniew Herbert i, jeśli się nie mylę, Holandia była pierwszym krajem, w którym przetłumaczone i wydane zostały wiersze zebrane pisarza. Niektórzy krytycy holenderscy twierdzą, że popularność poety wiąże się z tym, że wykreowany przez niego Pan Cogito ma w sobie pewne elementy kalwinistyczne, jest to postać raczej sceptyczna, racjonalistyczna, a charakterystyczne dla niej ascetyczność i powściągliwość odpowiadają holenderskiemu protestantyzmowi. Z kolei twórczość poetycka Miłosza, którego wiersze są bardziej mistyczne i więcej w nich religijności, została wprowadzona do systemu holenderskiego nieco później, bo dopiero po roku 2000. Kiedy dostał Nagrodę Nobla, nikt tak naprawdę nie wiedział, kto to jest. Wtedy też ukazało się kilka jego książek, przede wszystkim zbiorów esejów, a sam Miłosz był przedstawiany jako pisarz polityczny, moralista, dysydent, który uciekł z Polski Ludowej. Dopiero kiedy po raz drugi tłumacze wprowadzili go do naszego systemu, został odkryty jako pisarz religijny i pojawiło się kilku pisarzy holenderskich, którzy zaczęli uznawać Miłosza za swojego patrona. Holandia to kraj mocno zlaicyzowany i choć ma on oczywiście tradycję protestantyzmu i w pewnych regionach religijność wciąż jest bardzo ważna, to bardzo silne jest tam tabu związane ze wszystkim, co dotyczy religii. Wybitny holenderski pisarz, Willem Jan Otten, który został wychowany w duchu ateistycznym, a w pewnym 
momencie nawrócił się na katolicyzm, odwoływał się właśnie do Miłosza, żeby uzasadnić swoją decyzję. Nie znajdując u siebie pisarza, który mógłby być przekonującym wzorem, wybrał polskiego poetę. U nas poeci religijni pozostają na marginesie, bo ten temat jest już nieaktualny. Kiedy więc Miłosz został po raz drugi wprowadzony do naszego systemu, zaczął służyć jako wzór dobrego, niedogmatycznego poety religijnego.

M.M.: Podobnie było właśnie w wypadku recepcji poezji Szymborskiej we Włoszech, o której wspominałam. Było w tym kraju kilka pisarek, które tworzyły w podobnej poetyce, przeciwstawiając się tradycji poezji hermetycznej, ale dopiero pojawienie się autorytetu w postaci noblistki spowodowało zmianę w układzie centrum-margines i dowartościowanie tego rodzaju twórczości. Chciałabym teraz jednak zapytać o nowe przekłady bardziej współczesnej literatury polskiej, bo jednak Herbert, Miłosz i Szymborska to przede wszystkim wiek XX.

\section{Kanon i społeczny status literatury}

K.V.H.: To może od razu powiem, że u nas nie ma kanonu literatury polskiej $\mathrm{i}$ to się wiąże z różnymi sprawami. U nas w ogóle koncepcja kanonu jest dosyć podejrzana i mało kto jej używa. W internecie krąży gdzieś oficjalny kanon literatury niderlandzkiej, ale nikt tak naprawdę z niego nie korzysta. W szkołach nie mamy list lektur, są pewne wskazówki, więc dzieci muszą czytać, ale nie ma żadnych lektur obowiązkowych, a nauczyciele mają bardzo dużo swobody. Ma to swoje plusy i minusy. Skoro więc nie mamy własnego kanonu, jeszcze trudniej byłoby wprowadzić obcojęzyczny.

M.M.: To bardzo interesujące, zwłaszcza w kontekście rozmowy o problemach edukacji polonistycznej, która ukazała się w czwartym numerze „Kontekstów Kultury” z 2019 roku. Rozmówcy zastanawiali się między innymi właśnie nad tym, jaką rolę odgrywa kanon lektur oraz kanon interpretacji w nauczaniu języka polskiego oraz jak bardzo szkodliwy zarówno dla uczniów, jak i nauczycieli jest brak swobody. Jak to wygląda w Belgii, co z egzaminami, w jaki sposób uczniowie i nauczyciele są rozliczani ze swoich obowiązków?

K.V.H.: Moi synowie kończą teraz szkołę średnią i co roku muszą czytać najwyżej dwie-trzy książki i mogą je sobie wybrać, a wybierają chyba często Harrýego Pottera. Wydaje mi się, że w tym roku mieli jedną lekturę obowiązkową z angielskiego, czyli Folwark zwierzęcy George’a Orwella - to jest taka klasyka. Pamiętam to ze swoich czasów, bo my też czytaliśmy tę książkę. U nas literatura odgrywa po prostu mniej ważną rolę - w edukacji, kulturze i wydaje mi się, że to różni kulturę polską i niderlandzką. $U$ was literatura wciąż ma ogromne 
znaczenie, jest obiektem sporów politycznych, jak w przypadku Herberta, Miłosza, Szymborskiej...

M.M.: Teraz także wokół Tokarczuk...

K.V.H.: Właśnie, a u nas nie ma czegoś takiego, to znaczy niewielu jest pisarzy, którzy byliby tak ważni, żeby ich twórczość stała się przedmiotem jakiegokolwiek konfliktu społecznego czy wojny kulturowej. Pisarze czasami biorą udział w różnych debatach, zabierają głos, ale to jest jeden z wielu głosów, a nie głos autorytetu. U was chyba społeczna rola literatury, czyli tradycja dziewiętnastowieczna, która w pewnym sensie nadal trwa, jest znacząca. U nas rynek odgrywa bardzo ważną rolę, czyli pytanie o to, co się sprzedaje, a co nie.

M.M.: Myślę, że i u nas to jest bardzo ważne. A jeśli chodzi o społeczny status literatury, też mamy problem z czytelnictwem, a szczególnie z czytaniem po maturze. Szczelny kanon lektur i szczelny kanon interpretacji odstraszają uczniów i oczywiście są pasjonaci, którzy później nie rezygnują z czytania, ale jest też sporo osób, dla których przygoda z książkami kończy się po egzaminie z języka polskiego. Odnośnie do szumu medialnego, jaki pojawił się wokół Tokarczuk, i sporów politycznych o jej twórczość, nie są one niestety dyskusją wnikliwych czytelników, co byłoby pewnie ożywcze. To zazwyczaj kłótnie ludzi, którzy opierają się na recenzjach czy wyjętych z kontekstu cytatach z powieści albo z publicznych wypowiedzi pisarki w mediach.

K.V.H.: Ale nawet dla Tokarczuk tradycja związana ze społeczną funkcją literatury jest w jakimś sensie istotna. Widać to na przykład w odczycie noblowskim, w którym kładzie bardzo silny nacisk na to, jaką rolę mają odgrywać różne narracje. Nie mogę sobie wyobrazić niderlandzkiego pisarza, który napisałby taki odczyt, bo u nas rola literatury jest po prostu dużo mniejsza. Wydaje mi się, że ten odczyt to też pewnego rodzaju przykład myślenia utopijnego - zwłaszcza fragmenty o narracji czwartoosobowej, która z jednej strony obejmowałaby różne fragmentaryczne narracje pierwszoosobowe, a z drugiej przedstawiała pewną spójną całość. Nie mogę sobie wyobrazić pisarza niderlandzkiego, który prezentowałby taką wizję literatury.

M.M.: Wydaje mi się, że Tokarczuk jednak bardzo szeroko rozumie narrację jako każdy akt opowiadania o świecie, więc to mogą być także narracje polityków, dziennikarzy. Choć oczywiście ma Pan rację, że ten szczególny rodzaj opowiadania o świecie jest, według niej, zarezerwowany dla pisarzy.

K.V.H.: Tak, pamiętam też, że Tokarczuk dość pozytywnie pisze również o serialach, ale to powieść jest dla niej najpełniejszym modelem narracji, ponieważ stanowi zamkniętą całość, zbiór fragmentów, który ostatecznie tworzy pewną spójną wizję. Seriale często nie mają zakończenia. 
M.M.: Wspomina także, że te otwarte zakończenia seriali nie zawsze wynikają z ich fabuły, ale są tworzone w taki sposób z myślą o ewentualnym kolejnym sezonie...

\section{Pisarz to ten, kto patrzy z lotu ptaka - wykłady noblowskie Miłosza i Tokarczuk}

K.V.H.: Pisarka wiele mówi o czułości, o potrzebie więzi, która łączy ludzi, a do tego jest potrzebne podejście psychologiczne, doświadczenie, ukazanie przeżyć wewnętrznych. Dyskursy polityczne często mają charakter ekskluzywny, czyli nie łączą, ale tworzą podział na „my” i „oni”. Kiedy czytałem ten odczyt po raz pierwszy, miałem wrażenie, że to pewnego rodzaju powrót do paradygmatu romantycznego, tylko że Tokarczuk rozumie romantyzm dużo szerzej, nie spogląda na tę epokę przez pryzmat narodowy, bo chyba ani razu w jej wykładzie nie pada słowo „polski” czy „Polska” w sensie konkretnej tożsamości narodowej. Jeśli jednak chodzi o rolę narracji i koncepcję narratora, pisarka widzi to bardzo szeroko i w sposób nieco utopijny. Nie wiem, czy Pani pamięta odczyt noblowski Miłosza, ale widzę w tych tekstach bardzo dużo ciekawych zbieżności, bo Miłosz także prezentuje bardzo utopijne, powiedziałbym niemniej romantyczne podejście do roli pisarza - to ten, kto stara się pogodzić wszelkie sprzeczności, ponieważ widzi wszystko z lotu ptaka...

M.M.: No tak, Cudowna podróż Selmy Lagerlof...

K.V.H.: Tak, on leci na grzbiecie tej gęsi i obejmuje wzrokiem całość, a jednocześnie widzi wszystko, każdy szczegół, mamy więc do czynienia z podwójnym widzeniem. Pisarz dostrzega fragment, ale jednocześnie ma wizję całości, silne jest w nim pragnienie powrotu do utraconej jedności, które chyba także u Tokarczuk często się pojawia. Powiedziałbym też, że Miłosz reprezentuje bardziej „męski” model patrzenia, często używa metafory myśliwego, pisarz według niego jest kimś, kto poluje na rzeczywistość, chce ją wchłonąć i ogarnąć. Z kolei ta czułość Tokarczuk jest bardziej „kobieca”. Ostatnio też ukazał się niderlandzki przekład Prowadź swój ptug przez kości umartych i tam również można odnaleźć pewne nawiązania do Miłosza, jest William Blake, jest „ziema Ulro”, nawet Emanuel Swedenborg. Widzę więc pewną ciągłość w literaturze polskiej, jeśli chodzi o rolę pisarza i rolę wyobraźni, bo to jest chyba kluczowe u Blake'a.

M.M.: Ciekawa jestem, czy są już jakieś recenzje tej powieści. U nas przez długi czas była ona czytana jako głos polityczny w sprawie polowania na zwierzęta, ale Kremer we wspomnianym wyżej artykule pisze, że na przykład w recenzjach 
w Stanach Zjednoczonych ten polityczny kontekst nie był tak silnie eksponowany, a zwrócono natomiast uwagę na uniwersalny wymiar powieści mający swoje źródło między innymi w poetyce baśni.

K.V.H.: Ta książka ukazała się u nas dopiero dwa tygodnie temu, więc tych recenzji jest w tej chwili niewiele, ale chyba rzeczywiście istnieje taka tendencja w naszym stosunku do literatury polskiej, by odczytywać utwory w kluczu politycznym, jeśli w danym momencie pojawi się nagłośniony konflikt czy kryzys. Tokarczuk jest u nas obecna od 20 lat i chyba nikt do tej pory nie dostrzegf tego, że u niej ważna jest polityka. Myślę, że jej powieści zostały wprowadzone do naszego systemu, dlatego że u niej istotna jest narracyjność, opowiadane przez nią historie są ciekawe, ujmujące i uniwersalne, więc nie ma w nich żadnej otwartej polityki. Wydaje mi się, że teraz zagraniczni recenzenci zwracają uwagę na kontekst polityczny z powodu istniejącej w Polsce debaty toczącej się wokół Tokarczuk i przyznanej jej Nagrody Nobla. Do tej pory Tokarczuk była odbierana u nas przede wszystkim jako pisarka, która zabiera głos w sprawie globalizacji. W jej powieściach i opowiadaniach zawsze ważny był temat relacji między ludźmi, co w pierwszych tekstach podkreślała za pomocą symboliki jungowskiej. Starała się pokazać, że wszyscy jesteśmy ze sobą związani, ponieważ jesteśmy ludźmi, mamy te same sny, podobną podświadomość, a wszystkie obrazy, które krążą w kulturach, mają podłoże archetypiczne. To się chyba z czasem zmieniło. W pewnym momencie w jej powieściach pojawiło się więcej wątków związanych z podróżowaniem, wędrowaniem, nomadycznością. Przykładem są Ostatnie historie, w których Tokarczuk prezentuje już inne podejście - są w nich historia, kontekst wschodnioeuropejski i wielopokoleniowość, czyli opowieść babci związanej z Kresami i przesiedlonej na zachód Polski, matki, która wychowała się w czasie komunizmu, oraz wnuczki, która jest globtroterem, nie czuje się związana z ojczyzną, wędruje po świecie, a on jest jej domem. Już w tej powieści ważny okazuje się więc wątek globalizacji, migracji, wieloetniczności. To jest także coś, co różni Polskę i Niderlandy, ponieważ Polska była państwem wieloetnicznym przed drugą wojną światową, a u nas było odwrotnie - mieliśmy państwa narodowe, które powstały w XIX wieku, a dopiero po drugiej wojnie na skutek różnych fal migracji postkolonialnej powstawało u nas społeczeństwo multietniczne, wielojęzyczne. W Polsce było odwrotnie, ale jest wielu polskich pisarzy, którzy podejmują temat migracji. W latach osiemdziesiątych popularny stał się u nas Tadeusz Konwicki, ponieważ pisał o historii, o skomplikowanych historiach rodzinnych. Jeden z moich kolegów niderlandystów, Jerzy Koch, opublikował bardzo ciekawy tekst na temat popularności Konwickiego w Niderlandach, w którym stwierdził, że nasze zachodnioeuropejskie społeczeństwa cierpią na pewnego rodzaju ahistoryczność, ponieważ nie było u nas żadnych gwałtownych zmian historycznych z wyjątkiem drugiej wojny światowej i okupacji, po których wszystko jednak wróciło do normy. Od wielu lat cieszymy się spokojem i z tego powodu zaczęliśmy 
zapominać o naszej historii, naszej tożsamości, a jednocześnie z różnych kolonii z wielu regionów świata zaczęli się pojawiać emigranci i wtedy właśnie zaczęliśmy się zastanawiać nad tym, co to znaczy tożsamość, czym są zmiany historyczne i jaki wpływ wywierają na społeczeństwo. Więc u nas ta refleksja nie była spowodowana doświadczeniem wojny czy sowietyzacji jak w Polsce, ale zetknięciem z emigrantami, doświadczeniem globalizacji. Tokarczuk chyba pasuje do tej tematyki, bo ona dużo o tym pisze.

M.M.: Kiedy słuchałam rozmów z tłumaczami Tokarczuk na język czeski, ukraiński, angielski i francuski, zwróciłam uwagę na to, że każdy z nich wskazywał właśnie na tematy globalizacji, migracji, zakorzenienia i niezakorzenienia jako na te najbardziej aktualne i uniwersalne zarazem. To między innymi one sprawiają, że twórczość pisarki odgrywa tak ważną rolę w obecnie zachodzących transferach między literaturą polską a innymi literaturami. Bardzo dziękuję za rozmowę. 